\title{
A Research on Eliminating Poverty for Zhouzhi County in an All-Round Way against the Backdrop of "County Directly under the Provincial Finance"
}

\author{
Ai Jian \\ Xi’an Peihua University, Xi,an, China
}

\begin{abstract}
Poverty alleviation program is the key political responsibility and development opportunity of the less developed areas in the Thirteenth Five-Year Plan, and the greatest livelihood projects related to the interests of the poor. "County directly under the provincial finance" is an important part of comprehensively deepening reform, and the firm support and guarantee for Zhouzhi County to alleviate poverty. This paper has described the concept of "county directly under the provincial finance", the meaning of poverty alleviation comprehensively and the significance to realize the aim of Zhouzhi county from a totally new perspective. From the situation of "county directly under the provincial finance", this paper has analyzed and summarized the changes and difficulties since Zhouzhi County enjoyed the benefit, and suggested that to realize building a moderately prosperous society in an all-round way and eliminating poverty comprehensively, Zhouzhi County need to make efforts in the aspects of politics, economy, culture, ecology and society. This paper has provided experience and precautionary measures for Zhouzhi County to improve and perfect the policy of "county directly under the provincial finance" and realize shaking off poverty in an all-round way, and set an example for other regions of Shaanxi province.
\end{abstract}

Keywords- "county directly under the provincial finance", Zhouzhi County, poverty alleviation in an all-round way

\section{INTRODUCTION}

"County directly under the provincial finance" is a kind of transformation of administrative relation among province, municipality and county from "province- municipality-county" to "province-county". In other words, the administration of county from current "province administrates municipalitymunicipality leads county" to "province directly administrate county". In general, there are two models about "province directly administrate county". On one hand, province directly administrates county financially. On the other hand, province directly administrates county in politics, economy, culture, society, ecology, etc. except finance. This administration model represents the perfection and development of China's market economy, breaks the shackles of the traditional administrative regions on the development of regional economy objectively, and it's conducive to the rapid and effective promotion of county economic development and the realization of poverty alleviation comprehensively.

This paper represents the phased research fruit of a school-level scientific project of the Xi'an Peihua University in 2017 called "a research on poverty alleviation for Zhouzhi County in an all-round way against the backdrop of "county directly under the provincial finance” (project code: PHKT17027).

\section{THE MEANING OF ALLEVIATING POVERTY} COMPREHENSIVELY AND FOR ZHOUZHI COUNTY TO COMPLETE

IT

Poverty has been always the key problem of the Communist Party and our government since the Party came to the office. The new generation of leading group of the Party Central Committee with $\mathrm{Xi}$ Jinping at the core even regards poverty alleviation for people as the top priority of party and state administration. President Xi Jinping proposed that more than 70 million poverty stricken population in China will shake off poverty by 2020 .

\section{A. The meaning of comprehensively alleviating poverty}

Poverty is about not only economy but also knowledge, idea, culture, information, resources, etc. Anti-poverty means to shake off poverty in economy, politics, culture, society and ecology for poor regions. Therefore, poverty alleviation is an all-round, multi-level, wide-field concept.

\section{B. The significance for Zhouzhi County to comprehensively alleviate poverty}

Zhouzhi County occupies an area of 2974 square kilometers, and has a population of 700600 . From the aspect of geological structure, it has mountains in the south and plain in the north. There are $76.4 \%$ mountainous areas and $900000 \mathrm{mu}$ cultivated land in Zhouzhi County, which forms a typical layout of about $70 \%$ mountains, $10 \%$ water and $20 \%$ cultivated land. As Zhouzhi County has a wide range of poverty, a large population of poverty and a deep degree of poverty, it is the main challenge for Xi'an to alleviate poverty. In 2012, Zhouzhi County was identified as the key county for poverty alleviation in Tsinling Mountains Area. It is a tough issue among the poverty alleviation in Xi'an as there are 137 poor villages and 113400 poor people---accounting for $21.4 \%$ in the total agricultural population of the county. [1] Therefore, poverty alleviation is the key for Zhouzhi County, getting rid of poverty comprehensively is a crucial step for Zhouzhi County to realize leapfrog development and respond to build a moderately prosperous society comprehensively in China. To realize "comprehensive poverty alleviation" in Zhouzhi County is the essential requirements of socialism and the fundamental embodiment of the superiority of socialism.

It's an inevitable requirement to building a moderately prosperous society in an all-round way to realize 
“comprehensive poverty alleviation", which is an important part of building a moderately prosperous society in an allround way. To make economic, political, cultural, social, and ecological reforms and changes come true is the final stance and purpose of China's mass line and also the policy of benefiting people.

\section{THE CHANGES AND DIFFICULTIES OF ZHOUZHI COUNTY BROUGHT BY “COUNTY DIRECTLY UNDER THE PROVINCIAL FINANCE"}

"County directly under the provincial finance" has become the most important assistor of the economic development for Zhouzhi County since it has become the pilot county of Xi'an in July 2009.

\section{A. The changes of Zhouzhi County after implementing "county directly under the provincial finance"}

Zhouzhi County became the pilot county of "county directly under the provincial finance” in 2009. This project has given the county much more autonomous right, which has resolved the financial difficulty for the county in a certain level.

This project has directly arranged money and resources that Zhouzhi County needs, which equips the county with capital strength and development foundation, so the county can make development strategies and plans according to its own demands and features, and improve its interests through flat management to alleviate poverty earlier. Zhouzhi County has played an active role in taking its advantages as a county directly administrated by the province in tax rebate, transfer payment, financial settlement, special grant and capital movement since 2009. Zhouzhi County has improved its GDP, urbanization rate, employment rate, total revenue and expenditure of the region, the value of industrial production, the investment in fixed assets, the total retail sales of social consumer commodity, the per capita GDP, the added economic value of the non-public sectors, the expenditure in education, science, technology and culture, and the spending on agriculture, social security, health care and housing. Moreover, per capita disposable income of rural and urban residents has increased year by year. As the momentum, potential and enthusiasm of Zhouzhi County are effectively stimulated, it has made great improvement and changes in its GDP, fiscal expenditure and revenue, the knowledge and culture level, people's life, the education and medical level, social harmony, ecological environment, etc. As the ability, potential and endogenous ability of leaders of Zhouzhi County have been fully stimulated, they have changed the passive attitude of "waiting, depending and asking" when it was a traditional impoverished county, which is conducive to promoting the early realization of "comprehensive poverty alleviation” in Zhouzhi County.

Zhouzhi County has made better grade in social and economic assessment among all counties in the province after been directly administrated by the provincial finance. In 2015, the county ranked 54 in the assessment report of economic and social development among 82 counties in Shaanxi Province. Zhouzhi County has been identified as the key poverty alleviation county in Tsinling Mountains Area with a per capita net income less than 2,500 yuan, 137 poverty-stricken villages and 113,400 poor people in the county, accounting for $21.4 \%$ of the county's agricultural population since 2012, and the county has eliminated poverty for 8182 households and 28091 people (including 14100 absolutely poverty-stricken population) in 2013, 9710 households and 34919 people in 2014, 14816 households and 50473 people in 2015 through seven projects after implementing "county directly under the provincial finance”. Zhouzhi County has realized poverty elimination in terms of some standards of the province and state.

\section{B. The difficulties in front of Zhouzhi County}

In the process of striving ahead, Zhouzhi County also met some problems such as its fiscal right reformation is lagging behind severely, the leader management system is not perfect, the comprehensive quality of the county is not high enough, and the reformation in some sectors is not in place. Xi'an Municipal Government still administrates Zhouzhi County's fiscal affairs. For example, the ecological compensation of the Hei River water source of Zhouzhi County was made by the municipal government in the form of transfer payment. The special fund for transfer payment was 570.9 million Yuan during 2013 to 2015, among which 401.27 million Yuan came from the municipal government. Zhouzhi County, among 13 counties and districts in Xi'an, has ranked almost the last one in economic development since 2009 up to now. The GDP ratio between Zhouzhi County, the lowest one and Yanta Dsitrict, the highest one was 1:11.6 in 2009, 1:11.3 in 2010, 1:10.4 in 2013, 1:10.96 in 2014, 1:7.7 in 2015, and 1:10.7 in 2016.[2] Zhouzhi County was the only one whose GDP hadn't reached ten billion among the 13 counties and districts. Zhouzhi County has hindered the whole economic development of Xi'an and slowed down the pace to become moderately prosperous in an all-round way.

Although Zhouzhi County implemented the policy of "county directly under the provincial finance", it was an impoverished county in Xi'an with poor foundation and many debts, and the fiscal support came from the provincial government after it being directly administrated by the province were almost used to solve these debts occurring during its development, so the investment in scientific education, culture and health, social security and environment was far less than needed. We can see that the number of health workers of every 10 thousand people stepped back to 11 in comprehensive economic development in 2015, and the financial difficulties and the problems of disposable financial resources in Zhouzhi County haven't been solved effectively. However, administrative pressure of provincial apartment has been increased after the implementation of "county directly under the provincial finance", and some problems and difficulties of Zhouzhi County that needed to be solved by the provincial government can't be settled effectively in first time. In addition, supporting measures of reformation are not perfect. The four measures approved in 2009 did not mention how to divide the administrative and social management powers between municipality and county. 
IV. IMPLEMENT THE POLICY OF “COUNTY DIRECTLY UNDER THE PROVINCIAL FINANCE” IN ZHOUZHI'S MANAGEMENT SYSTEM TO REALIZE TOTALLY POVERTY ALLEVIATION

Zhouzhi County has shaken off poverty in 2015. However, to achieve directly provincial administration in economic, political, cultural, social and ecological fields and realize poverty elimination in an all-round way, the provincial government needs to deepen the extent and intensity of the policy and delegate more comprehensive social and economic management power to the local government.

\section{A. Promote "county directly under provincial government" in the political system}

The provincial government, the municipal government in Shaanxi and Zhouzhi county should cooperate closely, and the provincial government should draw lessons from other provinces that have successful experience in "county directly under the provincial finance" such as Zhejiang Province, Hainan Province, etc., so as to enlarge its management field, scale and special items and delegate financial, administrative and social management power to the local government. It should positively carry out the content and spirit mentioned in the [2009] 94 document, solve problems in the process of delegating and transferring power to the lower levels while give more free developing zone for Zhouzhi County. The provincial government should positively support the work of Zhouzhi County when distributing capital and bidding projects, and directly examine, supervise and assess the performance of the county. The county should exert its subjective initiative based on "county directly under the provincial finance", and the county government should fasten its docking with the provincial government while striving for more delegated powers. Combine and promote "county directly under the provincial finance" with the self-reformation of the village together to shake off poverty as soon as possible. At the same time, the government needs to carry out the idea of targeted poverty alleviation put forward by the Party Central Committee rather than chanting empty slogans, and carry out "seek true poverty, alleviate true poverty and alleviate poverty practically" proposed by president $\mathrm{Xi}$, so as to bring more benefits to poor people.

Mentally regard "poverty alleviation" as a key idea in deepening "county directly under the provincial finance" for Zhouzhi County.

The main political task of the government during the Thirteenth Five-Year Plan is to alleviate poverty according to the documents of the Party Central Committee. Mentally, the county government should regard "poverty alleviation" as a long-term target policy to realize a normal state of "poverty alleviation”. Take "poverty alleviation” for Zhouzhi County as the primary political task of the government. In the condition of "county directly under the provincial finance", the government should take the lead to establish a responsibility system which connects poverty alleviation with leader performance assessment. We should carry out poverty alleviation with full mobilization and a series of poverty alleviation activities in the form of science, education, industry, giant, etc. to build a society that all people take part in the activities.
B. Enhance infrastructure construction, such as road, promote "one village one specialty", and vigorously develop advantaged industries with characteristics through "county directly under the provincial finance" in the field of economy

To alleviate poverty, we must find out the root at first and then make clear the direction. [3] There are many poor situations in Zhouzhi County such as bad geographic position, wicked ecological environment, lagging infrastructure (including bad road situation and behindhand irrigation and water conservancy construction), insufficient investment, simplex plants, and the poor ability to master market information and national strategy timely and accurately.

1) Speed up infrastructure construction, such as road traffic and water conservancy

As the saying goes: "Building road is the first step to become rich." Zhouzhi County should promote the quality and improve the efficiency of road traffic construction in povertystricken villages based on current road situation there, so as to exert the leading role of convenient transportation in the process of becoming rich. Zhouzhi County should take advantage of the political opportunities as a poverty county in the state-level to fight for project construction capital and increase the municipal fiscal ratio, and implement and perfect "The Road Construction Plan of "Four-Virtue Road in Villages' in Zhouzhi County" on the above basis, so as to provide the county with firm traffic guarantee in regional economic development and poverty alleviation.

2) Vigorously promote and deepen the industrialization of "one village one product"

Establish management committee of special industrial demonstration park with comprehensive agricultural developing advantages in Zhouzhi County, promote positive fiscal policies to make the industrialization of kiwi fruit industry, fruit-bearing forest industry, trees and flowers industry, gold and stone industry and vegetable industry orderly and healthily. This is a way to deepen the reform of "one village one product". At the same time, positive measures and policies should be adopted to strengthen financial service in rural and urban area, and realizing poverty alleviation with capital, industrial, employment and labor transformation supports finally.

\section{Intensify the extent and effort of basic education and educational training through "county directly under the provincial finance" in the field of culture.}

In terms of education training, people in poverty-stricken areas should have confidence in self-escaping from poverty, interrupting the transmission of poverty from generation to generation, strengthening technical training for people in poor areas, improving vocational education and training for poor people and poor regions, providing students with targeted training in poor regions, publicizing scientific and technological propaganda to farmers, cultivating new type of professional farmers, improving the employment environment in poor regions, enhancing the practice about independent innovation and entrepreneurship in poor areas, enhancing the self-development of talents in poor regions. All of these must 
have the support of a great deal of money. As Zhouzhi County has been a poor county for 15 years with difficult fiscal condition, abundant capital support from "county directly under provincial finance" is essential to realize poverty elimination for the county.

\section{Enhance the concern on livelihood issues and try harder to solve them through "county directly under provincial \\ finance" in the field of social construction}

Poverty alleviation needs not only the support of government and state, but also a harmonious and better environment constructed by people that have gotten rid of poverty. For example, enhance community services and relevant supporting services, improve the system of elderly care service, help Zhouzhi people to improve life quality in housing, food security, dilapidated building reconstruction for poor people especially the disabled. Improve the nutrition for children in poor villages, build new kindergartens, enhance public medical service and guarantee, pursue poverty alleviation in the aspect of health to eliminate situations, such as people are too poor to afford medical treatment, disease leads poverty or makes people return to poverty, help household enjoying the minimum living guarantee or those are really poor, urban low-income households and families with financial difficulties, improve the guaranteed income supplement standard in rural and urban areas, and enhance education funding efforts. Give financial subsidies to poor families in rural and urban areas, increase the medical aid for disabled people, actively promote cultural and sports activities, broadcasting and broadband networks in rural areas, and broadband construction projects that benefit people.

\section{E. Implement a series reformation in ecology to build a beautiful Zhouzhi through "county directly under provincial finance"}

Zhouzhi County should take advantage of the benefit; more actively use natural resources to make Zhouzhi a county that established on ecology. For example, strengthen the heating sewage treatment facilities, adjust the sewage treatment projects in Jixian Industrial Park, manage rural garbage and sewage in a deeper level, strengthen the management on environmental, and people should promote environmental protection, popularize clean energy, enhance the construction of ecological town, build a beautiful Zhouzhi through these methods.

\section{CONCLUSION}

Under the condition of "county directly under provincial finance”, Zhouzhi County should take advantage of the opportunities of reform and targeted poverty alleviation to rectify and reform 57 problems in 9 categories that affect "poverty alleviation" of Zhouzhi, draw up targeted measures according to the resources features and practical reasons of poor villages, and take advantages of natural resources in Zhouzhi County to make Zhouzhi County strong in ecology, industry, characteristics, science and education, finally realize poverty alleviation in Zhouzhi County.

\section{REFERENCES}

[1] Yan Kun, Implement Measures Simultaneously and Carry Out Strategies Accurately to Alleviate Poverty-An Exclusive Interview of Yang Xiangxi- the Secretary of Zhouzhi County Committee, Xi'an Daily, $21^{\text {st }}$ March 2016, the $3^{\text {rd }}$ edition.

[2] The data cited is from Xi'an statistical bureau, the data of counties and districts,county GDP during 2009-2016.

[3] Mark the points! Understand the five years since the $18^{\text {th }}$ national congress from 100 gold sentences for ruling state and dealing with politics of Xi Jinping

http://news.ifeng.com/a/20170814/51629704_0.shtml 